\title{
Homestay Industry -Drivers and Challenges in the State of Johor, Malaysia
}

\author{
Azlina Md. Yassin, NorjariahArif \\ Faculty of Technology Management and Business, University Tun Hussein Onn Malaysia, 86400 Parit \\ Raja, BatuPahat, Johor, Malaysia \\ JeyaLechumy A/P Perumal Naidu \\ Faculty of Technology Management and Business, University Tun Hussein Onn Malaysia, 86400 Parit \\ Raja, BatuPahat, Johor, Malaysia \\ *Corresponding Author: azlina@uthm.edu.my
}

\begin{abstract}
The growth in Malaysiantourism industry has led to high demand for homestayas a tourism product, albeit indirectly. With thatgrowth, it has been acknowledged that homestay accommodation business plays a significant role in aiding the success of the tourism industry in Malaysia.There arealready a large number of registered homestay entrepreneurs and the number is growing. The main aim of this paper isto examinethe factors that contribute to thegrowth of homestay industry in Johor.The conceptis introduced while the drivers and barriers to the business are also discussed in this paper. A literature review was earlier undertaken on homestayentrepreneurships around the worldto offer some measure of comparison.
\end{abstract}

Keywords: Barriers, Concept, Challenges, Drivers, Homestay

\subsection{INTRODUCTION}

Service sector forms a major component of the economy in Malaysia together with the other sectors i.e. industrial, manufacturing and agriculture. According to Malaysian Investment Development Authority (MIDA), tourism industry has significant importance towards Malaysia's economy in general and the service sector in particular, apart frombanking and financialservices, and trading services, real estate and telecommunication services (MIDA, 2012).Malaysia's tourism sector saw a jump inimprovement, from being fifth to the third highest Gross National Income (GNI) contributor in 2014 despite thedeclines in tourist arrivals and receipts (Bernama, 2016).Due to high potential of tourism industry as an encourager and stimulator of the country's socio-economic development, the government of Malaysiain 2004 restructured the Ministry of Arts, Culture and Tourism (MOCAT) into three new ministries which include the Ministry of Tourism Malaysia (Amran, 2004). The Ministry was assigned mainly to coordinate and implement government policies and strategies pertaining to tourism industry. As a result of the continuous efforts of the Ministry of Tourism, the tourism industry had experienced a rapid growth and gained importance in Malaysianeconomy. Apparently, the sub-industries of tourism that contributed to this growth are eco-tourism, medical tourism and cultural or heritage tourism. These sub-industries are supported by various tourism products one of whichis homestay. 
The Malaysian government took an initiative to upgrade tourism industry by introducing Malaysia Homestay Programmewhich was launchedofficially by Ministry of Tourism Malaysia on 3rd December 1995 in Temerloh,Pahang.The main aim of introducing homestayprogramme under RuralTourism Master Plan is to encourage rural participation in the tourism sector(Ministry of Rural and Regional Development, 2010). The Homestay Programmegained its popularity only in recent years (Ministry of Tourism Malaysia, 2010). Thus this study aims to offer a preliminary insight into the homestayindustry in Malaysia through an examination of the concept, drivers and challenges, and factorsthat promote thegrowth of thesectorin Johor.

\subsection{HOMESTAY AND HOMESTAY BUSINESS}

Homestay was earlier defined as a private home in which unused rooms are rented for supplementing income and meeting people (Lanier and Berman, 1993).In Malaysia, homestay concept accommodation was first identified around 1970s in Kampung Cherating Lama, Pahang where a local lady called 'Mak Long' accepted a long staying 'drifter enclave' and provided breakfast, dinner and accommodation within her village house (Yusof et al., 2012). Inthe beginning, the pioneers of homestay were located on sites along the beach. During 1980s, the homestay concept took another dimension when local families accepted Japanese youths to stay with them under an exchange programme. Since then, the Ministry of Agriculture had been usinghomestay as acatalyst for rural development (Yusof etal., 2012).

The homestay programme in Malaysia was initially organised by communities in rural areas asa specific form of rural cultural tourism promoted by the Malaysian government (Musa et al., 2010). Visitors then would have the opportunities to visit rural villages and attractions and experience hosts' culture, while the hosts have the opportunities to be a part of the tourism product and to receive more of the socio-economic benefits from it.The Ministry of Tourism Malaysia (2010) has also expressedhomestay as an arrangement that provides accommodation for students and tourists in the home of host family in exchange for payment where the packages include a homestay in a traditional village, accommodation arrangement for students and school groups; and live with a local family in homestay and learn the language and culture of the locals.

\subsection{Registered Homestay vs. Unregistered Homestay}

Registered homestaysare registered under the Malaysia Homestay Programme as required by the Ministry of Tourism Malaysia. The registered homestay entrepreneurs are the homestay coordinators and homestay operators who manage, handle and run the homestays as a source of income.Unregistered homestays are meant to operate as a guesthouse where only lodgingaccommodation are provided for tourists but at ratescheaper than for hotel and other means of accommodation. The unregisteredhomestay operators are those who run the homestay in aresidential or housing area without any licence from the Ministry of Tourism Malaysiaand local authorities and not following the concept as indicated in the MalaysiaHomestay Programme's Homestay Guidelines.

\subsection{Concept of Homestay - Malaysia vs International Context}

In Malaysia, homestay is a tourism product which is not categorised as an accommodation facility. It focuses more on experience, lifestyle, culture and economic activities. Each homestay is meant to offer different activities based on the culture, traditional food, economicactivities of the place (Malaysia Tourism Ministry, 2011). Malaysian Homestay Programme aims to share the benefits of tourism industry with all walks of life in Malaysia by encouraging participation of rural community in the tourism industry. The 
benefitsare to comprise the following:to increase income and improve the living standard of rural community by providing a chance to make income through tourism industry; to produce tourism entrepreneurs in rural community; to provide a unique experience to tourists or visitors who are keen to experience life and culture of rural community; and to create rural hospitality tourism products with competitive price and international standard(Malaysia Tourism Ministry, 2011).

In international context, homestay can be distinguished from othertypes of accommodation that are being offered in terms of the specific culture associations such as privatehomes, interaction with a host or hostfamily, sharing of space which thereby becomespublic. Homestay is a private home where thetourist pays directly or indirectly to stay (Lashley \& Morrison, 2000).In international market, Homestay Programs are used as anaccommodation option for foreign students who coming to study in their countriesand the international students are considered as the new niche for thehomestay industry.

In western countries, the rural tourism concepts are also known as agriculturetourism or agro-tourism which enables tourists to enjoy the lifestyle of a farmer (Roberts and Hall, 2011). Agro-tourism is different from normal homestay programmes because it doesn't involve a whole community of the village in arrangingtourism activity since the farms are well off located within a large land area. So, agro-tourismonly involves the families of the farmers in arranging the tourism activities.

Table 2 below provides a summary of the homestay practices from different countries.

Table 2: Homestay Practices from International Approach

\begin{tabular}{|c|l|c|}
\hline Country & Details \\
\hline Canada & - Homestay Programme is conducted in the rural areas or farm areas. \\
& - These rural areas are situated in an area where there are no transportation facilities \\
available and the visitor has to depend on the host or travel by their own vehicle. \\
- The most attractive aspects about the Canadian Homestays are the dynamic of \\
Canadian families where the family members usually have deep discussion, good \\
communication and strong family bond among each other. Other aspects that \\
attract a lot of tourists to the homestay are a lot of quality time spent with hosts \\
family and the chance to participate in the recreational and cultural activities such \\
as camping,eating North American food and easy access to nature (Crealocketal., \\
1999). \\
\hline - In Australia, homestay provides services that are called "home away from home" \\
to students and tourists for weeks or months where the homestay is referred to as \\
bed and breakfast accommodation or student accommodation (Akbar etal., 2004). \\
- In Australia, the students can only stay in homestays that are selected and \\
approved by Australian government. \\
- Homestay is the best option of accommodation because it enables interaction \\
between different types of culture which indirectly promotes multicultural \\
understandings. \\
- The Australian Homestays are giving importance to safety factors where the hosts \\
undertake to get police clearance before they open their houses to tourists. \\
- Staying in a homestay is the best way to learn how to live in Australia and is also \\
\hline
\end{tabular}




\begin{tabular}{|c|c|}
\hline Country & Details \\
\hline & much cheaper and safer compared to other accommodations that are available. \\
\hline Japan & $\begin{array}{l}\text { - Homestay hasgained popularity in Japan because the Japanese want their country } \\
\text { and culture to be known worldwide and the homestay is the best medium of } \\
\text { accommodation which can make this possiblecompared to the expensive hotels. } \\
\text { - Japan Homestay Programme provides the tourists and students with the } \\
\text { opportunity to become a part of local Japanese family and learn and experience } \\
\text { their language, culture, customs and lifestyle personally. } \\
\text { - The homestay host families are carefully selected by the International Homestay } \\
\text { Organisation and all the selected homestays are registered under the Japan } \\
\text { Homestay Programme (Kleipinger, 1995). } \\
\text { - There are a lot of benefits in staying in homestay in Japan, especially for students } \\
\text { - they can practise the Japanese language they learn at education institutes while } \\
\text { staying with the host family, get the chance to listen to the native speaking } \\
\text { Japanese language and learn to cook Japanese foods. } \\
\text { - There are several forms of homestay services provided in Japan such as short-term } \\
\text { study abroad programme that lasts from } 2 \text { months to years, weekends homestays, } \\
\text { university exam homestays, corporate training homestays and working holiday } \\
\text { homestays. }\end{array}$ \\
\hline India & $\begin{array}{l}\text { - The Indians love to have guests in their houses due to the belief 'Athiti Devo } \\
\text { Bahva' which means guests are equal to god and feel honored to have guests in } \\
\text { their homes. } \\
\text { - This is why Indian hospitality is so famous around the world and a homestay is } \\
\text { the best place to experience it. } \\
\text { - The homestay concept in India is as same as "Bed and Breakfast" concept of } \\
\text { western countries where the guests are accommodated in the host's house or } \\
\text { quarters nearby. } \\
\text { - The homestay of India enables the guests to personally experience and develop a } \\
\text { healthy relationship with the hosts through courtesy and the warmth of home- } \\
\text { cooked foods served showed by the hosts will surely touch the souls of the guests } \\
\text { (Gangotia, 2013). } \\
\text { - The homestay in India began from Kerala a decade back and ever since it has } \\
\text { shown a significant growth in number until today. } \\
\text { - The charm of homestay is that it allows the tourists to enjoy the hospitality of real } \\
\text { India in terms of uniqueness of accommodation, personalized service, practical } \\
\text { local information on travelling places and reasonable fair prices, home-cooked } \\
\text { food and enjoy various activities which they will otherwise miss by choosingto } \\
\text { stay in hotels (Gangotia, 2013). } \\
\text { - In India, there are several cities that have created a niche for themselves in } \\
\text { homestay industry besides all the other homestays through the hospitality and } \\
\text { desirability of the homestays. }\end{array}$ \\
\hline
\end{tabular}




\begin{tabular}{|l|l|}
\hline Country & \multicolumn{1}{c|}{ Details } \\
\hline & $\begin{array}{l}\text { In India, the homestay programme is provided widely for international students } \\
\text { who come to study there to enable them to develop Hindi language skills and get } \\
\text { the chance to eat their traditional foods. } \\
\text { - The host families for the homestay programme are chosen from the middle- and } \\
\text { upper-middle class communities who have professional backgrounds (Gangotia, } \\
\text { 2013). }\end{array}$ \\
\hline
\end{tabular}

\subsection{Growth of Homestay Industry in Malaysia}

In Malaysia, homestay tour packages are receiving good response and have been growing in demand in recent years. Most of the tourists prefer to choose the homestaywhenever they visit the country as they are more interested in getting toknow and experience the culture and lifestyle of the local community. Since they would not have the opportunity to experience and learn theculture and way of life of the locals if they were to stay in hotels, these tourists prefer to stay inhomestay. With this consideration, thegovernment has given support and encouragement to the development of homestayas the tourism product and now almost every state in Malaysia has its own Homestay Program (Ibrahim, 2010).

The most successful homestayprogramme in Selangor is Kampung Banghuris of Sepang District programme. The main attraction of thisplace is its agricultural activities as $90 \%$ of its land area is used for agriculture. Thisprogramme has managed to attract a variety of tourists from Britain, Japan, China, otherAsian countries as well as those from the Eastern regions to Malaysia. This homestay programme has become a modelhomestayto other state governments who are interested in carrying out similarprogrammes.

The homestay programme has attracted a lot of tourists to Malaysia ever since it was first implemented (Yahaya \& Fauzaw, 2008). By 2011, the number of homestays that registered under Ministry of Tourism Malaysia as shown in Table 1hadincreased to 150 throughout Malaysia (Tourism Malaysia, 2011).

Table 1: Malaysia Homestay Statistics (Until December 2011)

\begin{tabular}{|l|c|c|c|c|}
\hline \multicolumn{1}{|c|}{ State } & $\begin{array}{c}\text { Number of } \\
\text { Homestays }\end{array}$ & $\begin{array}{c}\text { Number of } \\
\text { Villages }\end{array}$ & $\begin{array}{c}\text { Number of } \\
\text { Participants }\end{array}$ & $\begin{array}{c}\text { Number of } \\
\text { Rooms }\end{array}$ \\
\hline Perlis & 3 & 3 & 56 & 64 \\
\hline Kedah & 14 & 19 & 296 & 393 \\
\hline Pulau Pinang & 9 & 9 & 200 & 227 \\
\hline Perak & 6 & 30 & 231 & 308 \\
\hline Selangor & 15 & 18 & 458 & 660 \\
\hline Melaka & 7 & 7 & 115 & 173 \\
\hline Negeri Sembilan & 9 & 27 & 231 & 354 \\
\hline Johor & 16 & 35 & 478 & 623 \\
\hline Kelantan & 6 & 7 & 133 & 133 \\
\hline
\end{tabular}




\begin{tabular}{|c|c|c|c|c|}
\hline Terengganu & 6 & 6 & 104 & 106 \\
\hline Pahang & 14 & 19 & 249 & 376 \\
\hline Sarawak & 26 & 28 & 353 & 357 \\
\hline Sabah & 16 & 25 & 228 & 438 \\
\hline Labuan & 3 & 3 & 79 & 97 \\
\hline TOTAL & 150 & 236 & 3211 & 4309 \\
\hline
\end{tabular}

Source: Homestay Unit (2011)

With the growth of the homestay industry, it has been acknowledged that a homestay accommodation business playsasignificantroleinaidingthesuccessofthetourismindustry in Malaysia (Ahmad et.al., 2014). As the state of Johor has the highest number of homestays as shown in the above table, this study has examined the drivers and challenges that are faced by the operators as entrepreneurs of these homestays.

\subsection{METHOD OF STUDY}

The study has conducted a questionnaire surveyon homestay operators tocollect information about the respondents' background and experience in the homestay business whichwas administered on 214 respondents from the six (6) sample homestays from four (4) districts of the State of Johor namelyHomestay Kampung Sri Paya, Kulai; Homestay FeldaSemenchu, Kota Tinggi;Homestay KampungLukut, Kota Tinggi; Homestay KampungTemeninBaru,KotaTinggi; Homestay KampungSinaranBaru, Johor Bahru; and Homestay KampungPerigiAcheh, PasirGudang.These six (6) registered homestays were chosen based on geographical factor which are situated near to each other at all the four (4) districts and had offered several attractive activities (refer Appendix 1 - the village-based agrotourism activities offered inhomestay).

Descriptive survey was conducted to identify the factors that contribute to the growth of homestay industry in the State of Johor. The factors that contribute to the growth of Malaysia homestayin the State of Johor are categorised into four categories based on the mean value range; namely, most dominant factors (mean = 3.50 to 4.00 ), dominant factors (mean $=3.00$ to 3.49 ), moderately dominant factors (mean $=2.99$ to 2.5 ) and least dominant factors (less than 2.49).

\subsection{RESULTS AND DISCUSSION}

The findings indicate that the most dominant reasons for the rural community to engage in the homestay industry are as follows: potential in the business (mean =3.77), pursuit ofown interest (mean $=3.70$ ), flexibility to manage time $($ mean $=3.59)$, desire to generate more income (mean $=3.54$ ) and personal satisfaction (mean $=3.53$ ). Other factors that are under consideration also include the following: having balance between work and family (mean $=3.43$ ), passion in business (mean $=3.36$ ), want to have a balanced lifestyle (mean $=3.33)$, having desire to own a business $($ mean $=3.30)$, encouragement by friend (mean $=3.13$ ) and wanting to prove ability to succeed (mean $=3.06)$. It is undeniable that other internal factors such as having been inspired by friend's success (mean $=2.99)$ and wanting to have control over own action (mean $=2.70$ ) are also substantial motives for deciding to involve in this emerging industry. 
These findings also suggest that the homestay entrepreneurs are not being forced to the homestay industry by any external forces. Rather, the prime motivation is because those entrepreneurs are able to see the opportunity or potential of the homestay industry and fondness to pursue something they enjoy doing.

There are four common problems that are addressed by the 214 homestay operators. The main problem faced by the homestay operators in running thehomestays is communication difficultywhere 169 operators (79\%) claimed that they face difficulties in communicating directly with thetourists due to their lack of proficiency in spoken English even with the help of language booklet provided by the Ministry of Tourism Malaysia. Other problems include dealing with tourists who are over demanding (9\%), homestay yields inconsistent with income (8\%) and time constraint (4\%) where homestay operators sometimes couldn't find time to entertain their guests due to workloads or receivingrelatives in their homes. It is important to identify relevant solutions to sustain the growth of the homestay industry in the future.

\subsection{CONCLUSION}

This paper aims to explain homestay business in Malaysia; to identify the concept, drivers and barriers that encourage homestay business and finally to share an experience from international approach in selected countries. From the literature review done, much information had been gathered and discussed in this paper. Generally, within Malaysia and many countries throughout the world sharealmost similar concept of homestay which provides services in form of accommodation where guests stay with host family under one roof or an arrangement that provides accommodation for students or tourists in the home of a family in exchange for payment. There were several factors that motivated the homestay business in Malaysia including the potential in the business, pursuit ofown interest - to own business, flexibility to manage time, desire to generate more income, personal satisfaction, passion in business, balance life style, wanting to prove ability to succeed, and inspired by friend's success.

On the other hand, it is evident that the homestay entrepreneurs faced some problems and challenges in managing and operating the homestay business in the State of Johor. Due to that, it is important to take necessary steps to solve those problems to ensure that the management and operation of the homestay business is more systematic and sustain its income.

\subsection{REFERENCES}

Ahmad S Z, JabeenFauzia, Khan M (2014), Entrepreneurs choice in business venture: Motivations for choosing home-stay accommodation businesses in Peninsular Malaysia, International Journal of Hospitality Management 36 (2014) 31-40

Akbar, H., Van Bael,T., Hussan,Y. \& Graeme, B. (2004). Evaluating the QUTHomestay Programme lessons learnt in providing quality services to international students. 15th ISANA International Education Conference Proceedings. Melbourne: ISANA International Education Association Inc. pp.1-14.

Amran, H. (2004). The evaluation of the Homestay programme in Malaysia:Performance, sustainability and challenge. Ministry of Tourism Malaysia. 
Bernama (2016) , NTP: Tourism sector 3rd highest contributor for Msian economy from https://www.nst.com.my/news/2016/04/141786

Crealock, E., Derwing, T. M., \& Gibson, M. (1999). To homestay or to stay home:The Canadian-Japanese experience. TESL Canada Journal/Revue TESL duCanada, 16(2), 53-61.

Gangotia, Amit (2013). Home Stay Scheme in Himachal Pradesh: A Successful Story of Community Based Tourism Inititatives (CBTIS). Global ResearchAnalysis, 2(2),pp.206\&2007.

Homestay Unit (2011). Tourism Development Department of Ministry of Tourism Malaysia.DirektoriPenyelaras Homestay. Dicapaipada April 13, 2013 darihttp://www.motour.gov.my/bm/muat-turun/doc download/5-senarai-penyelaras-home

Ibrahim Y. et al (2010). Homestay Programme and Rural Community Development inMalaysia. pp.13.

Kleipinger,L.(1995). The Australian/Japanese Homestay Programme and its PositiveContribution to CrossCultural Understanding. The Internet TESL Journal,1(1).

Lanier, P. , \& Bernam, J. (1993). Cornell Hotel and Restaurant AdministrativeQuarterly. Bed and breakfast inns comes of age.

Lashley, C and Morrison, A (eds.) (2000) In Search of Hospitality: TheoreticalPerspectives and Debates, Oxford: Butterworth-Heinemann.

MIDA (2012). Invest in Malaysia. Exracted on April 29, 2013 fromhttp://www.mida.gov.my/env3/index.php?page=policies-guidelines-andincentives.

Ministry of Rural and Regional Development (2010). Official Portal Ministry ofRural and Regional Development. Extracted on May 01,2013 fromhttp://www.rurallink.gov.my/.

Ministry of Tourism Malaysia (2010). Homestay Management. Official PortalMinistry of Tourism Malaysia. Extracted on April 27, 2013 fromhttp://www.tourismmalaysia.gov.my/.

Ministry of Tourism Johor (2011).Village- Base Agro-Tourism \& Homestay.Ministry of Tourism Johor. Extracted on May 01, 2013 from http://www.tourismjohor.gov.my/

Ministry of Tourism Malaysia (2011). Malaysia Homestay Programme. OfficialPortal Ministry of Tourism Malaysia. Extracted on April 27, 2013 fromhttp://www.motour.gov.my/.

Musa G, Kayat K, Thirumoorthi T (2010) The experiential aspect of rural home-stay among Chinese and Malay students using diary method. Tourism and Hospitality Research 10(1): 25-41

Roberts \& Hall (2001). Tural Tourism and Recreational Principle to practice. Scott:CABI Publishing. pp.36. 
Yahaya, I. \& Fauwaz, H. (2008). Programme Pelancongan Homestay dan komunitidesa. Pelancongan Malaysia: Isu pembangunan, Budaya, Komuniti danPersetempatan. Penerbit Universiti Utara Malaysia.m/s 172.

Yusof, Y., Amin, A. \& Muda, S. (2012). Developing Model of TransformationalLeadership And Organizational Commitment In Homestay Programme. Proc.of ICBER 2012. Bandung: Journal Of Global Business And Economics.pp.2. 
"Appendix - 1"

Activities Offered By Each Homestay

\begin{tabular}{|c|c|c|c|c|}
\hline No & Area & $\begin{array}{l}\text { Number of } \\
\text { homestay }\end{array}$ & Homestay & Activities \\
\hline \multirow[t]{3}{*}{1} & Pontian & 1 & $\begin{array}{l}\text { Homestay Kampung } \\
\text { Puteri Menangis }\end{array}$ & Pineapple, herbs and oil palm plantation \\
\hline & & 2 & Homestay Tg. Piai & $\begin{array}{l}\text { National Park; Coconut Square; 'Gasing' square; } \\
\text { Bugis meseum; Bee farm; "kelong" farming; } \\
\text { chalet }\end{array}$ \\
\hline & & 3 & $\begin{array}{ll}\text { Homestay } & \mathrm{Kg} . \\
\text { Permatang Pasir } & \end{array}$ & Pineapple and palm oil plantation; Fruit factory \\
\hline 2 & $\begin{array}{l}\text { Johor } \\
\text { Bahru }\end{array}$ & 1 & $\begin{array}{l}\text { Homestay Kg. } \\
\text { Gunung Pulai }\end{array}$ & $\begin{array}{l}\text { Tropical fruit orchard; Hydroponic farm; } \\
\text { Mushroom farm; Rubber and oil palm plantation; } \\
\text { Aquaculture; Local handicraft; Gunung Pulai } \\
\text { Recreational Park Orchid valley }\end{array}$ \\
\hline 3 & $\begin{array}{l}\text { Batu } \\
\text { Pahat }\end{array}$ & 1 & $\begin{array}{l}\text { Homestay Kg. } \mathrm{Sg} . \\
\text { Sarang Buaya }\end{array}$ & $\begin{array}{l}\text { Paddy field; Rubber tapping \& oil palm } \\
\text { plantation; Pineapple \& tropical fruit farm; Fresh } \\
\text { coconut juice; Mangrove swamp; River cruise } \\
\text { tour; Handicraft \& cottage industry; Water } \\
\text { sports; Grisek Hot Spring; Palm sugar processing }\end{array}$ \\
\hline \multirow[t]{2}{*}{4} & Muar & 1 & $\begin{array}{l}\text { Homestay Kg. parit } \\
\text { Bugis }\end{array}$ & $\begin{array}{l}\text { Grisek Hot Spring; Rubber Tapping \& Oil Palm } \\
\text { Plantation }\end{array}$ \\
\hline & & 2 & $\begin{array}{l}\text { Homestay Kg. Batu } \\
\text { Baru } 28\end{array}$ & $\begin{array}{l}\text { Small \& medium industry; Rubber tapping and } \\
\text { oil palm Plantation; Malay culture }\end{array}$ \\
\hline 5 & Kluang & 1 & $\begin{array}{lll}\text { Homestay } & \text { Kg. } & \text { Sri } \\
\text { lukut } & & \end{array}$ & $\begin{array}{l}\text { Kahang Organic Eco Farm; Resort; "Pusat } \\
\text { Ternak Haiwan Padang } \\
\text { Hijau"; Zenxin Organic Park; Mountain } \\
\text { climbing at "Gunung Lambak" }\end{array}$ \\
\hline 6 & Mersing & 1 & $\begin{array}{l}\text { Homestay Kg. } \quad \text { Air } \\
\text { Papan Laut }\end{array}$ & $\begin{array}{l}\text { Turtle sanctuary; Paddy field; Batik; " keropok } \\
\text { lekor"; Island Tour }\end{array}$ \\
\hline \multirow[t]{2}{*}{7} & $\begin{array}{l}\text { Kota } \\
\text { tinggi }\end{array}$ & 1 & Homestay Kg. lukut & $\begin{array}{l}\text { Tropical Fruit Orchard; Lukut Fishing; Gunung } \\
\text { Panti Rainforest; Rubber tapping }\end{array}$ \\
\hline & & 2 & Homestay & $\begin{array}{l}\text { Fish, goat and cow farming; Frozen traditional } \\
\text { industry (small \& medium industry); Plantation }\end{array}$ \\
\hline
\end{tabular}




\begin{tabular}{|c|c|c|c|}
\hline & & Semenchu & pitaya, chilli and mushroom \\
\hline & 3 & $\begin{array}{ll}\text { Homestay } & \mathrm{Kg} . \\
\text { Temenin Baru }\end{array}$ & $\begin{array}{l}\text { Tropical fruit orchard; Fruit and vegetable farm; } \\
\text { Jungle trekking; Coffee processing; Waterfall; } \\
\text { Rubber and oil palm plantation }\end{array}$ \\
\hline Kulai & 1 & $\begin{array}{l}\text { Homestay Felda Sg. } \\
\text { Ara }\end{array}$ & Kayaking; Boat ride; Fishing; Karaoke; Cycling \\
\hline Skudai & 1 & $\begin{array}{l}\text { Homestay } \\
\text { Sinaran Baru }\end{array}$ & $\begin{array}{l}\text { Mushroom farm; Fruit farm; Rubber and oil palm } \\
\text { plantation }\end{array}$ \\
\hline Kulai Jaya & 1 & $\begin{array}{l}\text { Homestay Kg. } \\
\text { Paya }\end{array}$ & Mushroom farm; Local food; 'Tempe' Enterprise \\
\hline $\begin{array}{l}\text { Pasir } \\
\text { Gudang }\end{array}$ & 1 & $\begin{array}{l}\text { Homestay Kg. Perigi } \\
\text { Acheh }\end{array}$ & $\begin{array}{l}\text { Camp site; River Cruise;"Panglima Acheh" } \\
\text { grave; Recreational Forest Mangrove Tree; " } \\
\text { Perigi Acheh"; Local food - lemang, seafood, } \\
\text { ketupat; Crocodile farm }\end{array}$ \\
\hline
\end{tabular}

